\title{
PENINGKATAN LITERASI INFORMASI UNTUK MENDUKUNG PEMBERDAYAAN PEREMPUAN DI DESA SARIWANGI KECAMATAN PARONGPONG KABUPATEN BANDUNG BARAT
}

\author{
Neneng Nuryati, Kelompok MKU, Politeknik Negeri Bandung, \\ neneng.nuryati@polban.ac.id \\ Ediana Sutjiredjeki, Jurusan Teknik Elektro, Politeknik Negeri Bandung, \\ ediana@polban.ac.id \\ Carolina M. Lasambouw, Kelompok MKU, Politeknik Negeri Bandung, \\ carolina.magdalena@polban.ac.id
}

\begin{abstract}
ABSTRAK
Peran perempuan dalam memajukan kesejahteraan keluarga dan bangsa sangat penting, terutama bagi Indonesia yang jumlah penduduknya perempuan > laki-laki. Guna mendukung pemberdayaan perempuan telah dilaksanakan Peningkatan Literasi Informasi untuk Ibu-ibu Kader PKK dan Pengurus Pokja Desa Sariwangi. Desa ini adalah satu di antara tujuh desa di Kecamatan Parongpong yang berpenduduk 16.318 jiwa, dan tergabung dalam 4.125 Kepala Keluarga, sekitar 700 di antaranya tergolong keluarga pra-sejahtera.

Peningkatan Literasi Informasi merupakan kegiatan Pengabdian Masyarakat Politeknik Negeri Bandung bekerjasama dengan Kelurahan Sariwangi. Tujuannya adalah meningkatkan kompetensi Literasi Informasi 21 Kader PKK dan Pengurus Pokja untuk mendukung tugas mereka mengelola 13 Posyandu multifungsi.

Peningkatan Literasi dilaksanakan selama 6 minggu melalui pelatihan menggunakan metode partisipatori-kolaborasi. Kompetensi yang diharapkan dikuasai oleh peserta, yaitu menentukan sifat dan cakupan informasi, mengakses informasi secara efektif menggunakan komputer, mengevaluasi informasi secara kritis, menggunakan informasi untuk merancang program, dan mengkomunikasikan informasi menggunakan kata-kata sendiri yang tepat.
\end{abstract}

Berdasarkan evaluasi, keterampilan Literasi Informasi 21 orang ibu-ibu rumah tangga kader PKK dan Pengurus Pokja di Desa Sariwangi telah berhasil ditingkatkan. Kesulitan merencanakanprogram PKK, dan menyusun pelaporan dapat diatasi melalui pencarian informasi yang lengkap, relevan dan akurat. Bukti keberhasilan adalah telah disusun 15 Rencana Program Kerja PKK yang siap dilaksanakan untuk tahun anggaran 2018.

Kata kunci: Kompetensi, Literasi Informasi, Pemberdayaan Perempuan, Desa Keyword: Competency, Information Literacy, Women empowerment, Village 


\section{PENDAHULUAN}

\subsection{Latar Belakang}

Peran perempuan dalam memajukan kesejahteraan keluarga dan bangsa sangat tinggi. Semua putra-putra terbaik yang membesarkan Indonesia adalah berasal dari dukungan ibunya (Jokowi, 2017). Pada saat ini jumlah penduduk perempuan lebih banyak dari jumlah penduduk laki-laki. Asumsinya, apabila semua perempuan Indonesia diberdayakan, maka negara Indonesia akan lebih cepat menjadi Negara yang makmur dan sejahtera. Oleh karena itu, program Pembinaan Kesejahteraan Keluarga (PKK) perlu didukung karena merupakan gerakan nasional pemberdayaan dan kesejahteraan keluarga yang tumbuh dari masyarakat bawah dengan prinsip pengelolaan DARI, OLEH dan UNTUK masyarakat. Motor penggerak PKK adalah perempuan, yang mayoritasnya adalah ibu-ibu rumah tangga. Menurut Asriani (2010), perempuan harus bisa menjaga kestabilan rumah tangga di tengah kecamuk pola kehidupan yang beragam. Bahkan tidak jarang perempuan turut berkontribusi mendukung perekonomian keluarga.

Di jaman perkembangan teknologi komunikasi sekarang ini, perempuan harus mampu mengikuti perkembangan yang ada. Terutama untuk memberikan dukungan terhadap kebutuhan anakanaknya. Oleh karena itu, perempuan, khususnya ibu rumah tangga minimal harus mempunyai kompetensi literasi informasi untuk mendukung peningkatan kesejahteraan keluarga. Pemikiran ini selaras dengan pemikiran Kartini (Widiyaning, 2013)yang dituangkan dalam salah satu surat yang dikirim kepada sahabatnya Rosa Abendanon dari Belanda, sebagai berikut:

"Dari perempuanlah manusia pertama kali menerima pendidikan... dan makin lama makin jelas bagiku bahwa pendidikan yang pertama kali itu bukan tanpa arti bagi seluruh kehidupan. Dan bagaimana ibu-ibu bumi putra dapat mendidik anakanaknya jika mereka sendiri tidak berpendidikan?....bukan hanya untuk perempuan saja, tetap iuntuk seluruh masyarakat Indonesia, pengajaran kepada anak-anak perempuan akan merupakan rahmat."

Literasi informasi menjadi kebutuhan bagi para perempuan, sehingga perlu disediakan wadah dan akses untuk peningkatan literasi informasi bagi ibuibu rumah tangga. Literasi informasi mencakup kemampuan dalam mencari, menggunakan dan mengevaluasi informasi yang dibutuhkan secara efektif dan efisien serta dapat mengembangkan pengetahuan baru (Martin.J, 2013; Tewell.E, 2015).

Sesuai dengan pendapat UTS (2004) dan Diljit Singh (2006) bahwa penggunaan informasi terdapat pada semua tingkat lapisan masyarakat, baik di rumah, tempat kerja, perguruan tinggi dan tidak terkecuali di luar sekolah, seperti halnya untuk ibu-ibu kelompok PKK. Cara penggunaan dan mengakses berbagai informasi dengan benar sangat diperlukan agar mereka dapat menyebarluaskan informasi yang diperlukan kepada ibu-ibu rumah tangga lainnya di lingkungan Desa tempat tinggalnya. Dengan demikian peningkatan kemampuan literasi para kader PKK menjadi sangat diperlukan. 
Namun demikian untuk meningkatkan kemampuan literasi para ibu-ibu kader PKK di suatu desa bukanlah hal yang mudah, karena keberagaman latar belakang dan tingkat pendidikan yang tidak merata di antara mereka. Oleh karena itu dibutuhkan suatu pembelajaran khusus agar kemampuan penggunaan informasi para ibu-ibu kader PKK dapat dikembangkan sesuai kebutuhan untuk mendukung kelancaran tupoksinya, seperti merencanakan program penyuluhan kesehatan, program peningkatan kesejahteraan, dsb.

Peningkatan literasi informasi dapat dilaksanakan melalui pembinaan terstruktur di bawah PKK, seperti yang telah diujicobakan pada kegiatan Pengabdian kepada Masyarakat (PkM) ini. Peningkatan literasi informasi dengan tujuan untuk meningkatkan literasi informasi 21 (dua puluh satu) orang kader inti PKK di Desa Sariwangi telah dilakukan pada periode bulan September - Oktober 2017. Kegiatan ini merupakan kerjasama antara Politeknik Negeri Bandung dengan Kelurahan Sariwangi

\subsection{Tujuan kegiatan PkM}

Kegiatan peningkatan literasi untuk ke 21(dua puluh satu) orang kader PKK tersebut ditujukan untuk:

- Memberdayakan ibu-ibu kader PKK agar dapat menjalankan tugas sesuai dengan fungsinya masing-masing,

- Membantu ibu-ibu kader PKK agar dapat mengakses informasi yang dibutuhkan secara efektif dan efisien serta dapat mengembangkan pengetahuan baru sesuai dengan keperluannya

- Meningkatkan keterampilan ibuibu kader PKK dalam merancang program kegiatan yang sesuai dengan tupoksinya.

\subsection{Manfaat Kegiatan}

Program peningkatan literasi kepada 21 (dua puluh satu) orang kader PKK Desa Sariwangi Kecamatan Parongpong diharapkan dapat mendukung tugastugas mereka sebagai pengelola 13 Posyandu yang bersifat multi fungsi, terutama dalam menyusun programprogram peningkatan kesejahteraan masyarakat yang akan berdampak pada peningkatkan perekonomian keluarga, hususnya keluarga pra-sejahtera. Sebagai sarana pendukung program peningkatan literasi informasi untuk warganya, Desa Sariwangi sedang berupaya untuk membangun Perpustakaan Desa. Keberadaan Perpustakaan Desa dirasakan sangat urgent sebagai sarana dan wadah bagi anak-anak maupun orang tua untuk mencari informasi yang diperlukan maupun untuk meningkatkan pengetahuan mereka.

\section{PERMASALAHAN}

Desa Sariwangi memiliki 4.125 Kepala Keluarga dengan jumlah penduduk 16.318. Diantara 7 (tujuh) desa yang dibina oleh Kecamatan Parongpong, Desa Sariwangi memiliki paling banyak keluarga yang tergolong pra-sejahtera, khususnya di RW 03, yaitu sekitar 700 Kepala Keluarga.

21 (dua puluh satu) orang kader inti PKK yang umumnya ibu-ibu rumah tangga dengan latar belakang 
DIFUSI

Volume 1, No.1 Januari 2018

pendidikan mayoritas adalah lulusan sekolah menengah pertama mempunyai tugas sebagai pengelola 13 Posyandu yang bersifat multi fungsi. Tugas-tugas 13 Posyandu ini terbagi menjadi 5 (lima) kelompok Bina Keluarga Balita; 4 (empat) kelompok Bina Keluarga Remaja dan 3 (tiga) kelompok Bina Keluarga Lansia. Untuk kelompok Bina Keluarga Balita, tugas yang dilakukan para kader PKK ini termasuk penyelenggaraan 15 kelompok Pendidikan Anak Usia Dini (PAUD) dan empat kelompok Usaha Peningkatan Pendapatan Keluarga Sejahtera (UPPKS).

Untuk menjalankan tugas-tugas tersebut tentunya bukan hal yang mudah, mengingat latar belakang pendidikan mereka. Secara umum mereka menhadapi kesulitan untuk menyusun program kerja dan anggaran yang diperlukan, dan sebelumnya mereka juga belum pernah mendapat pelatihan cara merancang program, mencari informasi untuk menyusun program dan juga merancang anggaran yang diperlukan. Salah satu cara untuk mengatasi masalah ini adalah membekali mereka dengan keahlian Literasi Informasi, sehingga mereka mampu mencari informasi yang diperlukan dan mengolahnya sesuai kebutuhan secara mandiri.

\section{METODE}

Selaras dengan tujuan kegiatan pengabdian masyarakat ini, maka pengetahuan dan keterampilan 21 (dua puluh satu) orang ibu-ibu kader PKK Desa Sariwangi Kecamatan Parongpong, Kabupaten Bandung Barat secara individual diharapkan dapat meningkat. Untuk mencapai tujuan ini maka telah diselenggarakan pelatihan Literasi Informasi, menggunakan metode Partisipatori dengan pendekatan kolaboratif. Metode Partisipatori digunakan agar peserta dapat berperan aktif dalam kegiatan pelatihan, sehingga lebih mudah dalam menyerap materi yang diberikan. Pendekatan kolaboratif dilakukan agar peserta merasa dihargai dan diajak bekerja sama untuk mengembangkan program-program sesuai tupoksinya serta sekaligus mengaplikasikan materi yang diperoleh. Dengan demikian pelatihan menjadi lebih efektif danberdaya guna.

Pelaksanaan kegiatan pengabdian kepada masyarakat ini dilakukan secara bertahap, seperti diperlihatkan pada Gambar 1 di bawah ini.

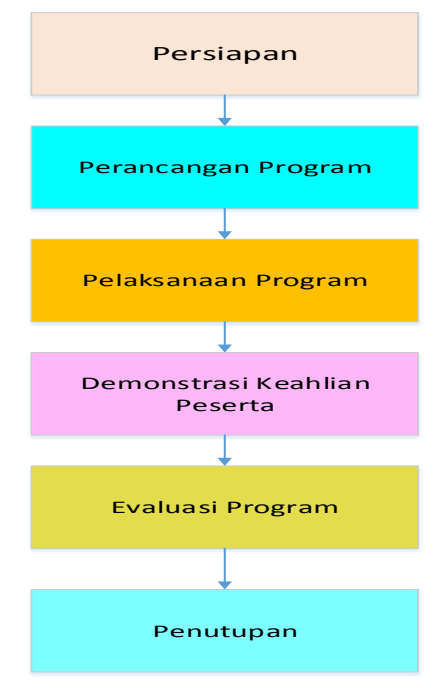

Gambar 1. Tahapan kegiatan PM

Pada tahap persiapan dilakukan kajian pustaka tentang kompetensi Literasi Informasi, aspek-aspeknya, cara peningkatan kompetensi literasi, dan cara mengevaluasi kemampuan Literasi Informasi. Pendekatan yang digunakan adalah Model Big 6. Pada model ini secara garis besar Literasi Informasi 
DIFUSI

Volume 1, No.1 Januari 2018

terdiri atas enam kompetensi utama, yaitu:

1. Mampu menentukan sifat dan cakupan informasi yang dibutuhkan

2. Mampu mengakses informasi yang dibutuhkan secara efektif dan efisien

3. Mampu mengevaluasi informasi dan sumber sumbernya secara kritis

4. Mampu menggunakan informasi untuk menyelesaikan tujuan tertentu

5. Mengkomunikasikan informasi dengan menggunakan kata-kata sendiri yang dapat dimengerti dan membuat daftar pustaka

6. Mampu memahami aspek yang berkaitan dengan penggunaan informasi.

Termasuk pada tahap ini adalah mencari data sekunder untuk memperoleh informasi demografi desa Sariwangi, kegiatan-kegiatan sebelumnya yang terkait pemberdayaan perempuan, serta mengidentifikasi peluang-peluang yang tersedia untuk meningkatkan kemampuan literasi perempuan.
Tahap perancangan diawali dengan melakukan identifikasi tingkat literasi kemampuan awal peserta terhadap materi pelatihan yang akan diberikan. Metode yang digunakan pada tahap ini adalah melalui wawancara terstruktur dan pertanyaan tertutup. Pada tahap ini, peserta didorong untuk memberi respon terhadap sejumlah pertanyaan yang telah dirancang sebelumnya. Berdasarkan data yang diperoleh, selanjutnya dirancang materi dan kegiatan-kegiatan pelatihan seperti diperlihatkan pada Tabel 1 di bawah ini. Pada tahap pelaksanaan program pertama-tama peningkatan pemahaman tentang literasi informasi. Hal tersebut dilakukan melalui sosialisasi dan Focus Group Discussion (FGD) mengenai pengertian, kegunaan dan contoh literasi informasi. Kegiatan selanjutnya adalah pelatihan mengakses informasi dari sumber media dan internet 


\section{DIFUSI}

Volume 1, No.1 Januari 2018

Tabel 1. kegiatan dan Materi Pengembangan Literasi Informasi

\begin{tabular}{|c|c|c|c|c|c|}
\hline No. & $\begin{array}{l}\text { Kompetensi Literasi } \\
\text { Informasi } \\
\end{array}$ & Materi & $\begin{array}{c}\text { Metode / } \\
\text { Aktifitas Peserta }\end{array}$ & Pedoman Bukti & $\begin{array}{l}\text { Pertemuan } \\
\text { Ke }\end{array}$ \\
\hline \multirow[t]{3}{*}{1.} & \multirow[t]{3}{*}{$\begin{array}{l}\text { Menentukan sifat dan } \\
\text { cakupan informasi } \\
\text { yang dibutuhkan }\end{array}$} & \begin{tabular}{ll}
\multicolumn{2}{l}{ Pendahuluan: } \\
- & Perkenalan \\
- & Tujuan program \\
- & Definisi Literasi \\
& informasi \\
- & Uraian program \\
& keseluruhan
\end{tabular} & $\begin{array}{l}\text { Diskusi } \\
\text { Tanya jawab } \\
\text { Peserta mengisi kuesioner }\end{array}$ & & 1 \\
\hline & & $\begin{array}{ll}\text { - } & \text { Pembagian Kelompok } \\
\text { sesuai tugas dan fungsi } \\
\text { - }\end{array}$ & $\begin{array}{l}\text { - } \\
\text { Peserta berlatih } \\
\text { mengidentifikasi kegiatan } \\
\text { POKJA yang sesuai dengan } \\
\text { tugas dan fungsi masing- } \\
\text { masing } \\
\text { Peserta membuat tabel } \\
\text { kegiatan sesuai POKJA }\end{array}$ & $\begin{array}{ll}\text { Tabel kegiatan } \\
\text { POKJA }\end{array}$ & 2 \\
\hline & & $\begin{array}{l}\text { Perumusan masalah } \\
\text { a. Merumuskan masalah } \\
\text { b. Metoda penyelesaian } \\
\quad \text { masalah }\end{array}$ & $\begin{array}{ll}\text { - } & \text { Peserta memilih dan } \\
\text { menentukan program } \\
\text { kegiatan } \\
\text { Peserta mengidentifikasi } \\
\text { masalah yang dihadapi } \\
\text { dalam kegiatan /program } \\
\text { yang dipilih } \\
\end{array}$ & $\begin{array}{ll}- & \text { Rumusan } \\
\text { masalah } \\
\text { - } & \text { Usulan } \\
& \text { program } \\
\text { - } & \text { Identifikasi } \\
\text { Kegiatan }\end{array}$ & 3 \\
\hline 2. & $\begin{array}{l}\text { Mampu mengakses } \\
\text { informasi yang } \\
\text { dibutuhkan secara } \\
\text { efektif dan efisien }\end{array}$ & $\begin{array}{ll}\text { - } & \text { Jenis- jenis sumber } \\
\text { informasi } \\
\text { - } & \text { Memilih sumber } \\
\text { informasi } \\
\text { - } \quad \text { Kelebihan dan } \\
\text { kekurangan masing- } \\
\text { masing jenis sumber } \\
\text { informasi } \\
\text { - } \quad \text { Alat untuk mengakses } \\
\text { informasi } \\
\text { Internet sebagai sumber } \\
\text { informasi masa kini } \\
\text { Pelatihan menggunakan } \\
\text { komputer }\end{array}$ & $\begin{array}{ll}\text { Peserta diberi contoh } \\
\text { berbagai sumber informasi, } \\
\text { seperti majalah, Koran, } \\
\text { buku, film, dsb. } \\
\text { Peserta dalam group harus } \\
\text { mengidentifikasi kelebihan } \\
\text { dan kekurangan setiap jenis } \\
\text { sumber informasi } \\
\text { Demo penggunaan } \\
\text { komputer sebagai alat bantu } \\
\text { untuk mencari informasi } \\
\text { melalui internet } \\
\text { Peserta mencoba } \\
\text { menggunakan komputer } \\
\text { untuk mengakses informasi } \\
\text { melalui internet }\end{array}$ & & 4,5 \\
\hline 3. & $\begin{array}{l}\text { Mampu mengevaluasi } \\
\text { informasi dan sumber } \\
\text { sumbernya secara } \\
\text { kritis }\end{array}$ & $\begin{array}{ll}\text { - } & \text { Memilih dan } \\
\text { mengidentifikasi } \\
\text { informasi yang } \\
\text { dibutuhkan } \\
\text { - } \quad \text { Metoda kata kunci } \\
\text { - } & \text { Mengelola informasi } \\
\text { menurut susunan yang } \\
\text { tepat } \\
\text { - Membedakan antara fakta } \\
\text { dan opini } \\
\text { Menggunakan alat bantu } \\
\text { visual untuk } \\
\text { membandingkan } \\
\text { informasi. }\end{array}$ & $\begin{array}{ll}- & \text { Peserta dipandu untuk } \\
\text { merancang satu program } \\
\text { sesuai dengan POKJA nya } \\
\text { Peserta mengidentifikasi } \\
\text { topik atau subjek, kata } \\
\text { kunci, dan jenis-jenis } \\
\text { sumber informasi. } \\
\text { Menggali informasi yang } \\
\text { sesuai dengan topik }\end{array}$ & $\begin{array}{l}\text { Daftar sumber } \\
\text { informasi yang } \\
\text { digunakan } \\
\text { Sumber } \\
\text { informasi yang } \\
\text { sudah dipilah dan } \\
\text { disusun sesuai } \\
\text { kebutuhan }\end{array}$ & 6,7 \\
\hline 4. & $\begin{array}{l}\text { Mampu menggunakan } \\
\text { informasi untuk } \\
\text { menyelesaikan tujuan } \\
\text { tertentu }\end{array}$ & $\begin{array}{ll}\text { - } & \text { Contoh Membuat } \\
& \text { Program sesuai POKJA } \\
\text { - } & \text { Mind mapping } \\
\text { - } & \text { Membuat daftar pustaka }\end{array}$ & $\begin{array}{ll}\text { - } & \text { Membuat format program } \\
\text { - } & \text { Menentukan tujuan dan } \\
\text { - } & \text { sasaran program } \\
& \text { Merancang dan menentukan } \\
\text { isi program } \\
\text { - } \quad \begin{array}{l}\text { Praktek mind mapping untuk } \\
\text { merancang program. }\end{array}\end{array}$ & $\begin{array}{l}\text { Draft program } \\
\text { dan kegiatan }\end{array}$ & 8,9 \\
\hline
\end{tabular}


DIFUSI

Volume 1, No.1 Januari 2018

\begin{tabular}{|c|c|c|c|c|c|}
\hline 5. & $\begin{array}{l}\text { Mengkomunikasikan } \\
\text { informasi dengan } \\
\text { menggunakan kata- } \\
\text { kata sendiri yang dapat } \\
\text { dimengerti dan } \\
\text { membuat daftar } \\
\text { pustaka }\end{array}$ & $\begin{array}{ll}- & \text { Teknik Presentasi } \\
\text { - } & \text { Membuat power } \\
& \text { points/slide untuk } \\
& \text { presentasi } \\
\text { - } & \text { Penyempurnaan program }\end{array}$ & 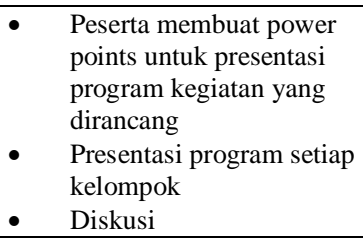 & Materi presentasi & 10 \\
\hline 6. & $\begin{array}{l}\text { Mampu memahami } \\
\text { aspek yang berkaitan } \\
\text { dengan penggunaan } \\
\text { informasi }\end{array}$ & $\begin{array}{l}\text { Dampak penggunaan Informasi } \\
\text { terhadap kemajuan ekonomi, } \\
\text { hukum, dan social sehubungan } \\
\text { dengan perkembangan } \\
\text { teknologi informasi }\end{array}$ & $\begin{array}{ll}- & \text { Ceramah } \\
- & \text { Diskusi } \\
\text { - } & \text { Permainan } \\
\text { - } & \text { Test }\end{array}$ & $\begin{array}{l}\text { Hasil kuesioner } \\
\text { /test }\end{array}$ & 11 \\
\hline 7. & $\begin{array}{l}\text { Evaluasi Program dan } \\
\text { penutupan }\end{array}$ & Post test & & Sertifikat & 12 \\
\hline
\end{tabular}

Sebagai bagian dari program Peningkatan Literasi ini, dilakukan pula pengayaan perpustakaan Desa Sariwangi agar dapat digunakan sebagai tempat pelatihan peningkatan literasi, sekaligus sebagai sarana sumber literatur.

Pelatihan peningkatan literasi telah dilaksanakan selama 60 jam dalam durasi enam (6) minggu. Pelaksanaannya dilakukan 2 (dua) hari dalam seminggu, yaitu pada setiap hari Senin dan Jum'at. Jumlah peserta program ini adalah 21 (dua puluh satu) orang yang terdiri dari ibu-ibu kader PKK dan pengurus POKJA PKK Desa Sariwangi Kecamatan Parongpong, Kabupaten Bandung Barat.

Sebelum kegiatan pelatihan ini berakhir, peserta dalam kelompok diberi kesempatan untuk memperlihatkan peningkatan kompetensi Literasi Informasi yang telah dicapai. Masingmasing kelompok mempresentasikan rencana program untuk tahun anggaran 2018 yang telah dirancang dengan mengacu kepada materi pelatihan yang telah diberikan. Selanjutnya sebagai akhir kegiatan dilakukan evaluasi kegiatan. Evaluasi terhadap penyampaian materi dilakukan oleh tim pelatih dan evaluasi terhadap penyelenggaraan pelatihan dilakukan melalui angket yang diisi oleh para peserta. Pada sesi penutupan, peserta dan tim pelatih menyampaikan kesan dan pesan mereka. Sebagai bentuk apresiasi terhadap peserta program, maka bagi peserta yang memenuhi syarat diberikat sertifikat dari Unit penelitian dan Pengabdian Masyarakat (UPPM) Polban.

\section{PEMBAHASAN}

\subsection{Pemberdayaan Perempuan di} Desa Sariwangi Kecamatan Parongpong Kabupaten Bandung Barat

Pada saat ini pemberdayaan perempuan merupakan fokus pengembangan dari pimpinan di desa Sariwangi Kecamatan Parongpong Kabupaten Bandung Barat. Hal ini dapat dilihat dari tersedianya berbagai program dan fasilitas yang disediakan oleh Kepala Desa untuk pemberdayaan perempuan serta dukungan dana yang diperlukan. Pemberdayaan perempuan dilakukan melalui penguatan kader PKK yang pada saat ini berjumlah sekitar 100 (seratus) orang. Kader PKK tersebut bertugas untuk mendukung berbagai kegiatan di Desa, diantaranya sebagai pengelola 13 Posyandu yang bersifat multi fungsi yaitu 5 kelompok Bina Keluarga Balita; 4 kelompok Bina Keluarga Remaja dan 3 kelompok Bina Keluarga Lansia. Terkait Bina Keluarga Balita, tugas yang dilakukan para kader PKK termasuk penyelenggaraan 15 kelompok Pendidikan Anak Usia Dini (PAUD) dan 4 kelompok Usaha 
Peningkatan Pendapatan Keluarga Sejahtera (UPPKS).

Kader PKK yang ikut serta mendukung kegiatan di Desa memiliki tingkat pendidikan yang beragam dengan rentang yang cukup panjang, yaitu SMP sampai dengan Sarjana (S1). Konsekuensi dari kondisi tersebut adalah perbedaan kemampuan literacy informasi. Dalam rangka mengatasi penyediaan kebutuhan informasi dari warganya, Kepala Desa memiliki program untuk mengembangkan perpustakaan Desa.

\subsection{Kemampuan Peserta dalam Literasi Informasi}

Untuk menjaring informasi mengenai kemampuan awal dari 21 (dua puluh satu) orang kader dan pengurus POKJA mengenaiLiterasi Informasi, maka telah dikembangkan instrumen assesment yang khusus. Instrumen ini berisi pertanyaan-pertanyaan yang sangat mendasar mengenai Literasi Informasi, dan pemanfaatan komputer sebagai alat bantu. Secara garis pertanyaan dapat dikelompokkan menjadi 3 (tiga) yaitu:

a. Mencari informasi.

b. Menemukan informasi; dan

c. Menggunakan komputer dan internet dalam mencari informasi.

Pada tahap awal pengukuran dilakukan melalui tanya jawab dengan peserta (Gambar 1).
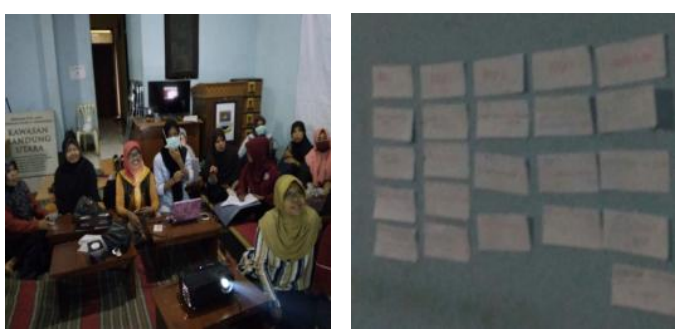

Gambar 1.

Aktifitas peserta

Hasilnya memperlihatkan bahwa ke-21 peserta belum pernah menerima pelatihan literasi informasi. Dengan demikian dapat disimpulkan bahwa semua peserta pada umumnya belum memiliki keterampilan dalam literasi informasi. Namun, demikian peserta sudah mengetahui cara mencari informasi yang diperlukan. Sebanyak $86 \%$ peserta sering memperoleh informasi dari media elektronika, sedangkan sisanya sebanyak $14 \%$ mencari informasi dari media non elektronika. Selanjutnya diketahui bahwa informasi yang banyak dicari adalah tentang dunia hiburan dan media elektronika yang digunakan adalah radio dan televisi. Untuk penggunaan media internet hanya 2 (dua) orang $(10 \%)$ dari 21 peserta yang bisa menggunakannya.

Berdasarkan data awal di atas, maka pelatihan Literasi Informasi ini diawali dengan materi Pengenalan Komputer, dan tahap-tahap cara penggunaannya untuk mencari informasi melalui internet. Selanjutnya peserta dilatih untuk mengelola informasi yang diperoleh, dan mengaplikasikan informasi sesuai dengan kebutuhan untuk merancang program-program kerja. 
Berikut adalah uraian lebih rinci mengenai hasil-hasil pengembangan Literasi Informasi yang telah dilaksanakan.

\subsubsection{Mencari informasi}

Berkaitan dengan tahap-tahap dalam pencarian informasi, 67\% dari pesera menyatakan selalu mengikuti tahaptahap pencarian informasi yang benar dan 33\% menyatakan kadang-kadang melalukan tahapan pencarian. Misalnya, jika untuk mencari informasi melalui koran, para peserta mencari kata kunci dari informasi yang akan dicari kemudian mereka membaca informasi yang tersedia. Selanjutnya, berkaitan dengan evaluasi terhadap informasi yang diperoleh, $28 \%$ peserta menjawab selalu melakukan evaluasi, 5\% menyatakan sering dan $67 \%$ menjawab kadang-kadang melakukan evaluasi terhadap informasi yang akan digunakan apabila memperoleh lebih dari satu informasi. Berdasarkan jawaban para peserta dapat disimpulkan bahwa rata-rata peserta kadang-kadang melakukan evaluasi bila mendapat beberapa informasi. Dengan demikian kemampuan awal para peserta adalah pada tingkatan dapat membaca.

Berkenaan dengan pertanyaan terkait pengolahan informasi untuk disebarkan kembali, ditemukan bahwa $10 \%$ dari peserta selalu mengolah informasi untuk disebarkan kembali, $5 \%$ sering dan $80 \%$ kadang-kadang serta 5\% tidak pernah mengolah informasi. Kesimpulannya, secara rata-rata peserta kadang-kadang melakukan pengolahan informasi untuk disebarkan kembali.

Respon peserta terhadap pertanyaan yang berkaitan dengan pencarian informasi, yaitu "apakah peserta selalu menggunakan cara tertentu dalam penelusuran informasi tersebut?". Jawaban peserta menunjukkan bahwa $19 \%$ dari peserta selalu menggunakan cara tertentu untuk menelusuri informasi, sedangkan $81 \%$ menjawab kadang-kadang. Kesimpulannya, secara rata-rata peserta tidak selalu menggunakan cara tertentu untuk penelusuran informasi.
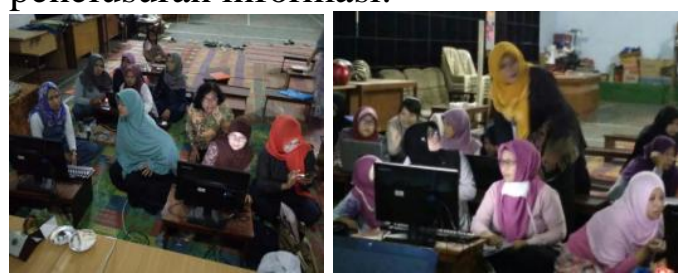

Gambar 2

Peserta sedang melakukan penelusuran informasi menggunakan internet

\subsubsection{Menemukan informasi}

Berkenaan dengan pertanyaan menemukan informasi dengan menggunakan komputer, ditemukan bahwa 10\% dari peserta selalu menggunakan komputer untuk menemukan informasi yang dicari, 5\% sering menggunakan komputer untuk menemukan informasi, dan $\mathbf{7 1 \%}$ kadang-kadang menggunakan komputer untuk menemukan informasi, serta $14 \%$ tidak pernah. Kesimpulannya, secara rata-rata peserta kadang-kadang menggunakan komputer untuk menemukan informasi.

\subsubsection{Menggunakan internet untuk mencari informasi}

Pencarian informasi dengan menggunakan internet, ditemukan bahwa $33 \%$ dari peserta selalu menggunakan internet, 5\% sering dan $62 \%$ kadang-kadang. Kesimpulannya, secara rata-rata peserta kadang-kadang menggunakan internet untuk mencari informasi 
Berkenaan dengan pertanyaan "Apakah anda menggunakan internet, hanya untuk informasi yang diinginkan ?", ditemukan bahwa 33\% dari peserta selalu menggunakan internet untuk mencari informasi, dan sisanya sebanyak $\quad 67 \% \quad$ kadang-kadang menggunakan internet, serta $5 \%$ tidak pernah mengolah informasi. Kesimpulannya, secara rata-rata peserta tidak selalu menggunakan internet untuk mencari informasi yang diperlukan/diinginkan.

\subsubsection{Menggunakan media lain untuk mencari informasi}

Berkenaan dengan pertanyaan "Apakah anda menggunakan internet, selain untuk mencari informasi seperti face book, you tube?", ditemukan bahwa $24 \%$ dari peserta selalu menggunakan internet selain untuk mencari informasi, dan sisanya sebanyak $10 \%$ sering, $62 \%$ kadang-kadang menggunakan internet, serta $4 \%$ tidak pernah menggunakan internet selain untuk mencari informasi. Kesimpulannya, secara rata-rata peserta kadang-kadang menggunakan internet selain untuk mencari informasi.

\subsubsection{Memilih informasi sesuai kebutuhan}

Berkenaan dengan pertanyaan "Apakah Anda dapat menentukan kebutuhan informasi program PKK sesuai dengan POKJA yang anda bawahi?, ditemukan bahwa $90 \%$ dari peserta menyatakan "YA" dan 10\% menyatakan "TIDAK". Kesimpulannya, mayoritas peserta dapat menentukan kebutuhan informasi program PKK yang sesuai dengan POKJA yang dibawahinya.

Untuk pertanyaan "Apakah Anda hanya memilih informasi yang paling tepat dan sesuai dengan kebutuhan?, ditemukan bahwa 95\% dari peserta menyatakan "YA" dan 5\% menyatakan "TIDAK". Kesimpulannya, mayoritas peserta dapat memilih memilih informasi yang paling tepat dan sesuai dengan kebutuhan.

\subsubsection{Menggunakan informasi}

Berkenaan dengan pertanyaan "Apakah anda menggunakan informasi yang diperoleh secara langsung?, ditemukan bahwa $38 \%$ dari peserta menyatakan "YA" dan 62\% menyatakan "TIDAK". Kesimpulannya, mayoritas peserta tidak menggunakan informasi yang diperoleh secara langsung.

\subsubsection{Menyimpan informasi}

Berkenaan dengan pertanyaan "Apakah Anda dapat menyimpan informasi yang diperlukan pada USB/Flasdisk?,ditemukan bahwa 33\% dari peserta menyatakan "YA" dan 67\% menyatakan "TIDAK". Kesimpulannya, mayoritas peserta tidak dapat menyimpan informasi yang diperlukan pada USB/Flasdisk.

Berkenaan dengan pertanyaan "Apakah Anda dapat menyimpan informasi yang diperlukan pada folder di laptop atau komputer?,ditemukan bahwa $29 \%$ dari peserta menyatakan "YA" dan 71\% menyatakan "TIDAK". Kesimpulannya, mayoritas peserta tidak dapat menyimpan informasi yang diperlukan pada folder di laptop atau komputer.

\subsubsection{Mencari informasi dari Flash Disk/Notebook/Komputer}

Berkenaan dengan pertanyaan "Apakah anda dapat mencari dan menemukan kembali informasi yang telah anda simpan di USB/flashdisk?,ditemukan bahwa $38 \%$ dari peserta menyatakan "YA" dan 52\% menyatakan "TIDAK". Kesimpulannya, mayoritas peserta tidak dapat mencari dan menemukan kembali 
informasi yang telah disimpan di USB/flashdisk.

Berkenaan dengan pertanyaan "Apakah anda dapat mencari dan menemukan kembali informasi yang telah anda simpan di folder di notebook atau komputer?, ditemukan bahwa $43 \%$ dari peserta menyatakan "YA" dan 57\% menyatakan "TIDAK" (Gambar 3). Kesimpulannya, sebagian besar peserta tidak dapat mencari dan menemukan kembali informasi yang telah disimpan di folder di notebook atau komputer.

\subsubsection{Perolehan informasi sesuai tujuan}

Berkenaan dengan pertanyaan "Apakah informasi yang anda peroleh selalu sesuai dengan tujuan program PKK pada POKJA anda?, ditemukan bahwa $71 \%$ dari peserta menyatakan "YA" dan 29\% menyatakan "TIDAK". Kesimpulannya, sebagian besar peserta dapat memperoleh informasi yang sesuai dengan tujuan program PKK pada POKJA yang dibinanya.

Berkenaan dengan pertanyaan "Apakah informasi yang anda perlukan untuk mendukung program PKK pada POKJA anda dapat diperoleh dengan biaya yang murah?,ditemukan bahwa 43\% dari peserta menyatakan "YA" dan 57\% menyatakan "TIDAK". Kesimpulannya, sebagian besar peserta tidak dapat memperoleh informasi dengan biaya yang murah.
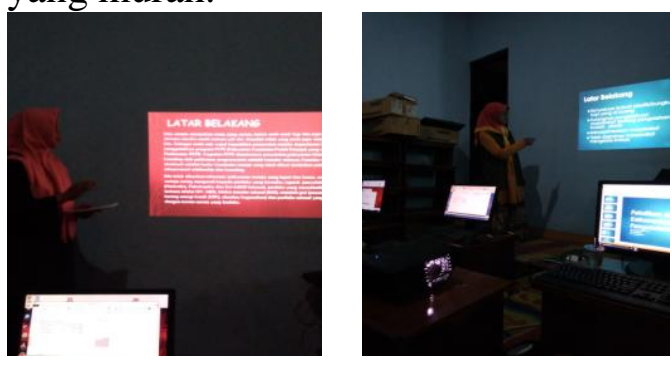

Gambar 3.

Peserta sedang mempresentasikan Rencana Kerja 2018 yang telah dibuat

\subsubsection{Aplikasi informasi yang diperoleh}

Berkenaan dengan pertanyaan "Apakah pengetahuan yang didapat dari POKJA dapat dengan mudah disampaikan kepada ibu rumah tangga atau ketua POKJA lain?,ditemukan bahwa 33\% dari peserta menyatakan "YA" dan $67 \%$ menyatakan "TIDAK". Kesimpulannya, sebagian besar peserta tidak dapat menyampaikan dengan mudah pengetahuan yang didapat dari POKJA kepada ibu rumah tangga atau ketua POKJA lain.

Berkenaan dengan pertanyaan "Apakah anda dapat mengaplikasikan informasi yang didapat mengenai kegiatan POKJA dengan membuka kegiatan berdasarkan hasil yang telah didapat dan diharapkan dapat membantu para ibu rumah tangga lainnya agar dapat membantu memperbaiki ekonomi keluarga mereka?, ditemukan bahwa $38 \%$ dari peserta menyatakan "YA" dan $62 \%$ menyatakan "TIDAK". Kesimpulannya, sebagian besar peserta tidak dapat mengaplikasikan informasi yang didapat mengenai kegiatan POKJA untuk membantu para ibu rumah tangga lainnya agar memperbaiki ekonomi keluarga mereka.

\subsection{Pelaksanaan Seluruh Kegiatan}

Untuk mengevaluasi seluruh kegiatan Peningkatan Literasi informasi yang telah dilakukan, maka dibuat kuesioner mengenai kepuasan peserta pelatihan. Pertanyaan yang diajukan meliputi:

1. Kesesuaian materi dengan kebutuhan peserta

2. Tingkat kesulitan materi untuk dipahami

3. Metoda penyampaian materi

4. Kualitas pemateri 
5. Waktu pelaksanaan

6. Sarana dan prasarana pelatihan

7. Tatakelola pelaksanaan pelatihan.

Tanggapan peserta terhadap pelaksanaan seluruh kegiatan pengabdian kepada masyarakat yang telah dilakukan selama 60 jam pada durasi 6 minggu, adalah seperti di bawah ini.

Mengenai kesesuaian materi dengan kebutuhan peserta, maka $67 \%$ peserta menyatakan bahwa materi yang diberikan cukup menarik dan sesuai dengan kebutuhan, sedangkan $33 \%$ menyatakan sangat sesuai dan menarik. Selanjutnya mengenai tingkat kesulitan materi untuk dipahami, maka

67\% peserta menyatakan tidak setuju terhadap pernyataan bahwa bahwa materi pelatihan sangat banyak dan sulit dipahami, sedangkan 33\% menyatakan sangat tidak setuju dengan permyataan tersebut.

Berkenaan dengan metoda penyampaian materi, maka $5 \%$ peserta menyatakan setuju bahwa Pemateri terlalu cepat dalam penyampaian materi, sehingga peserta kesulitan untuk mengikutinya. Sisanya $67 \%$ peserta menyatakan tidak setuju dengan pernyataan tersebut, dan $28 \%$ peserta menyatakan sangat tidak setuju terhadap pernyataan tersebut. Berkenaan dengan waktu pelaksanaan, maka $38 \%$ peserta menyatakan setuju bahwa waktu pelaksanaan terlalu singkat sehingga tidak semua materi selesai dibahas; $57 \%$ peserta menyatakan tidak setuju terhadap pernyataan tersebut, dan $5 \%$ peserta menyatakan sangat tidak setuju. Mengenai kualitas pemateri, maka 19\% peserta menyatakan tidak setuju bahwa pemateri kurang menguasai materi sehingga terlalu monoton dan kurang menarik. Sisanya $81 \%$ peserta menyatakan sangat tidak setuju terhadap pernyataan tersebut. Berkenaan dengan pelaksanaan yang tepat waktu dan tidak terlambat, $52 \%$ peserta menyatakan sangat setuju bahwa pelaksanaan tepat waktu dan tidak terlambat. Sisanya 33\% peserta menyatakan setuju terhadap pernyataan tersebut, dan $15 \%$ peserta menyatakan tidak setuju. Berkenaan dengan jumlah peserta terlalu banyak, tidak dibatasi sehingga suasana menjadi ramai, maka $5 \%$ peserta menyatakan setuju bahwa jumlah peserta terlalu banyak, tidak dibatasi sehingga suasana menjadi ramai. Sisanya $10 \%$ peserta menyatakan tidak setuju terhadap pernyataan tersebut, dan $85 \%$ peserta menyatakan sangat tidak setuju.

Berkenaan dengan ruang pelatihan yang terlalu sempit dan kurang nyaman, 33\% peserta menyatakan tidak setuju bahwa ruang pelatihan terlalu sempit dan kurang nyaman. Sebanyak $67 \%$ peserta menyatakan sangat tidak setuju terhadap pernyataan tersebut. Berkenaan dengan sistem kerja panitia yang kurang terorganisir sehingga terkesan kurang terkoordinir, $52 \%$ peserta menyatakan tidak setuju bahwa sistem kerja panitia kurang terorganisir dan kurang terkoordinir, sedangkan $48 \%$ peserta menyatakan sangat tidak setuju terhadap pernyataan tersebut.

\subsection{Peran Politeknik Negeri Bandung dalam Peningkatan Literasi Informasi}

Politeknik Negeri Bandung (Polban) sebagai lembaga pendidikan vokasional memiliki kewajiban untuk menyelenggarakan tri darma perguruan tinggi. Salah satu darma yang wajib dilaksanakan oleh Dosen Polban adalah kegiatan pengabdian kepada masyarakat. Mengacu kepada hasil studi pendahuluan di Desa Sariwangi, diketahui bahwa kader-kader PKK dan 
pengurus POKJA yang dibina oleh Ibu Ketua PKK, menghadapi kesulitan dalam membuat perencanaan programprogram dan penulisan laporan tahunan kegiatan Kader dan pengurus POKJA. Terutama berkaitan dengan pencarian informasi yang lengkap, relevan dan akurat.

Melalui kegiatan pengabdian masyarakat yang dilaksanakan oleh tim Dosen dari Polban telah dilatih 21 (dua puluh satu) orang kader PKK dan pengurus POKJA sehingga berhasil:

a) memperkuat pemahaman ke 21 (dua puluh satu) orang kader PKK dan pengurus POKJA tersebut mengenai pentingnya informasi dan bagaimana cara mencari, memilah, menyimpan dan menggunakan informasi yang tepat, relevan, lengkap dan akurat.

b) mengidentifikasi kegiatan-kegiatan yang diperlukan oleh warga binaan kader PKK dan pengurus POKJA tersebut.

c) mengidentifikasi berbagai sumber informasi dan mempraktekan cara mencari informasi yang sesuai dengan kebutuhan dari sumber informasi yang tepat.

d) mencari informasi menggunakan perangkat komputer dengan menggunakan internet.

e) menyimpan dan memanggil kembali informasi yang diperoleh,

f) membuat rencana program kegiatan kader PKK dan POKJA tahun 2018.

\section{SIMPULAN}

Peningkatan Literasi Informasi bagi 21 (dua puluh satu) orang ibu-ibu kader PKK Desa Sariwangi, Kecamatan Parongpong, Kabupaten Bandung Barat telah berhasil dilaksanakan dengan baik. Secara kelompok maupun individu, kemampuan Literasi Informasi ibu-ibu kader PKK tersebut telah meningkat dengan pesat, meskipun tidak seluruh kompetensi Literasi Informasi telah dikuasai (kompetensi ke 6). Hal ini terbukti dari perbedaan hasil evaluasi awal dengan hasil evaluasi yang signifikan. Jika sebelum program dilaksanakan hanya $86 \%$ peserta sering mencari informasi dari media elektronika (Radio dan TV), dan hanya $10 \%$ dari 21 peserta yang bisa menggunakan internet, maka setelah pelatihan ditemukan bahwa $33 \%$ dari peserta selalu menggunakan internet untuk mencari informasi, 5\% seringmenggunakan internet untuk mencari informasi, dan $62 \%$ kadangkadangmenggunakan internet untuk mencari informasi. Data ini memperlihatkan bahwa setelah pelatihan semua peserta $(100 \%)$ dapat menggunakan internet untuk mencari informasi yang diperlukan.

Di samping itu setelah pelatihan, mayoritas peserta (90\%) dapat menentukan kebutuhan informasi program PKK yang sesuai dengan POKJA yang dibawahinya, dan mayoritas peserta (95\%) dapat memilih memilih informasi yang paling tepat dan sesuai dengan kebutuhannya. Kedua keterampilan ini menjadi sangat penting dan berarti bagi 21 (dua puluh satu) orang ibu-ibu kader PKK tersebut, karena sebelumnya kedua hal tersebut tidak mereka kuasai sehingga mereka menghadapi kesulitan dalam menyusun program-program kerjanya.

Terkait dengan aplikasi informasi yang diperoleh sesuai dengan tujuan program PKK pada POKJA, maka setetelah pelatihan sebagian besar peserta $(71 \%)$ dapat memperoleh informasi yang sesuai dengan tujuan program PKK pada POKJA yang dibinanya. Hal ini juga sangat penting bagi pengembangan pengetahuan peserta. Dampak positif 
yang lain adalah mayoritas peserta yang semula lebih banyak mencari informasi tentang dunia hiburan dari radio dan televisi, maka setelah pelatihan ini dapat mencari informasi yang lebih bermanfaat, baik bagi dirinya maupun lingkungan di sekitarnya.

Selanjutnya peningkatan kemampuan literasi informasi tersebut dapat dijadikan daya ungkit untuk mendukung dan mentransfer peningkatan literasi informasi kepada ibu-ibu rumah tangga lainnya di Desa Sariwangi.Dengan adanya peningkatan literasi informasi, diharapkan ibu-ibu rumah tangga hususnya, dan perempuan di desa Sariwangi umumnya akan dapat memanfaatkan informasi yang berkaitan dengan peningkatan ekonomi atau wirausaha skala rumahan. Dengan demikian pada akhirnya akan dapat meningkatkan kesejahteraan keluarga mereka.

Luaran program peningkatan literasi ini adalah 21 (dua puluh satu) orang ibuibu kader PKK yang memiliki kemampuan literasi informasi. Selain itu, ke 21 (dua puluh satu) orang kader PKK tersebut telah mampu membuat rencana program kegiatan PKK yang lebih baik dengan informasi yang lengkap, akurat, dan relevan. Luaran lainnya adalah ketersediaan dokumendokumen Rencana Program PKK tahun 2018, sebagai hasil kerjake 21 (dua puluh satu) orang kader PKK tersebut.

\section{DAFTAR PUSTAKA}

\section{Asriani,DwiD.2010. Kesehatan Reproduksi Dalam Bingkai Tradisi Jawa, Yogyakarta}

Diljit Singh, 2006. School Libraries and Information Literacy.
Disampaikan pada: Seminar Perpustakaan Sekolah : peran lierasi informasi dan teknologi informasi komunikasi di perpustakaan sekolah dalam menunjang proses pembelajaran. Jakarta: Perpustakaan Nasional RI.

Martin. J, 2013, Information literacy learning from recent British information literacy models, https://files.eric.ed.gov/fulltext/ej1 089097.pdf, Communication in Information Literacy, Volume 7, Issue 2, 2013.

Pam Barnett, 2004, Setting A Strategic Direction For Information Literacy At The

University Of Western Australia, diunduh dari http://www.library.uwa.edu.au/ data/assets/pdf_file/0011/558929/ Setting_a_strategic_direction_for information_literacy_at_UWA.pdf

Tewell Eamon, 2015, A decade of critical information literacy: A review of the literature, 2015, Communication in Information Literacy, Volume 9, Issue 1, 2015. https://files.eric.ed.gov/fulltext/EJ 1089135.pdf.

University of Technology Sydney, 2004, Developing the information literate person: the UTS Framework and Strategic Plan, diunduh dari http://www.lib.uts.edu.au/sites/def ault/files/attachments/page/730_Fr amework.pdf

Widiyaning, 2013. Peranan PKK dan Pengaruhnya terhadap Kondisi Sosial Ekonomi Perempuan di Kota Semarang Tahun 1972-1998, 


\section{DIFUSI}

Volume 1, No.1 Januari 2018

Skripsi. Diunduh dari laman ....tanggal 11 Juni 2017 